\title{
Deprimert av p-piller?
}

I en ny studie har forskere påvist sammenheng mellom bruk av hormonelle prevensjonsmidler og depresjon.

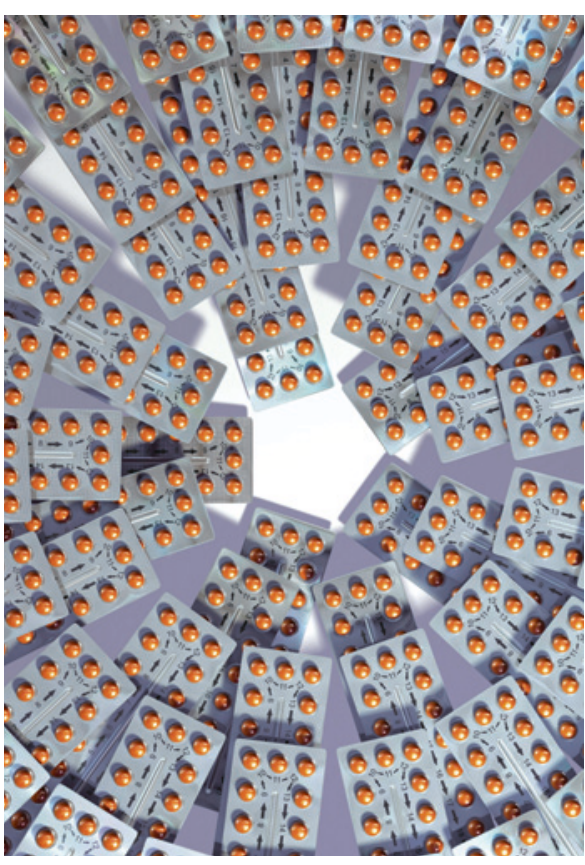

Illustrasjon: Science Photo Library
Flere studier tyder på at hormonelle prevensjonsmidler kan øke risikoen for utvikling av depresjon. I en ny dansk studie ble rundt én million kvinner i alderen 15-34 år fulgt i over 14 år fra 2000 (1). Dataene ble så koblet med det nasjonale reseptregisteret.

Bruk av kombinasjons-p-piller ga økt risiko for bruk av antidepressiver sammenlignet med dem som ikke brukte slike piller (rateratio $1,23 ; 95 \% \mathrm{KI} 1,22-1,25)$. Det samme gjaldt for bruk av progestinpiller, p-plaster (norgestrolmin), p-ring (etonogestrel) og hormonspiral (levonorgestrel). For alle brukere av hormonelle prevensjonsmidler sett under ett var insidensen («crude incidence rate») for førstegangs bruk av antidepressiver 2,2 per 100 personår, mens den for ikke-brukere var 1,7.

- Dette er en stor og pålitelig studie, sier Marius Johansen, medisinsk ansvarlig lege ved Sex og samfunn, landets største senter for seksuell og reproduktiv helse og rettigheter. - Vi har lenge visst at depresjon er en bivirkning av enkelte typer hormonell prevensjon, men det har vært vanskelig å fastslå en kausal sammenheng. Men jeg kunne ønsket meg en kontrollgruppe med kvinner som brukte kobberspiral, sier Johansen, som mener det blir feil å sette de forskjellige prevensjonsmidlene opp mot hverandre for å sammenligne hvilke som har høyest risiko for bivirkninger.

- I studien var risikoen for depresjon hos kvinnene som brukte hormonspiral høyere enn hos dem som brukte gestagenpiller eller vanlige p-piller. Det gir ikke mening rent farmakologisk, siden hormonkonsentrasjonen i blodet ved bruk av hormonspiral er en brøkdel av den man ser ved bruk av gestagenpiller, sier Johansen, som mener det kan ha vært metodiske forhold ved studien som gjør den vanskelig å fortolke.

- Valg av prevensjonsmiddel må alltid baseres på en totalvurdering som må gjøres i samråd med kvinnen. På Sex og samfunn hører vi altfor ofte historier om kvinner som er blitt avfeid av legen om at det må være andre ting i livet som gjør dem deprimerte eller gjør at de mister sexlysten, fordi forskning ikke kan bevise en slik sammenheng, sier Johansen. Han understreker at kvinner må få god informasjon om mulige bivirkninger før de starter med hormonell prevensjon.

- Det er viktig å presisere at de aller fleste som bruker hormonell prevensjon ikke blir deprimerte, sier Johansen.

\section{Ketil Slagstad}

Tidsskrifte

\section{Litteratur}

1. Skovlund CW, Mørch LS, Kessing LV et al. Association of hormonal contraception with depression. JAMA Psychiatry 2016. E-publisert 28.9.2016.

\section{Nytt og effektivt legemiddel mot atopisk eksem}

\section{Et nytt humant antistoff gir klinisk bedring ved atopisk dermatitt.}

Dupilumab, et humant monoklonalt antistoff mot interleukin-4-reseptor alfa, hemmer signaler fra to cytokiner som spiller en viktig rolle ved atopiske sykdommer, bl.a. atopisk eksem.

Nylig publiserte New England Journal of Medicine to randomiserte, placebokontrollerte fase 3-studier av dupilumab-behandling ved atopisk eksem (1). Studiene omfattet totalt 671 voksne pasienter med kronisk atopisk eksem av moderat til alvorlig grad. Pasientene ble behandlet i 16 uker, enten med ukentlige subkutane injeksjoner med dupilumab, dupilumab annehver uke eller placebo.

Nesten $40 \%$ av pasientene som ble behandlet med dupilumab, ble helt eller nesten helt kvitt sine eksemplager i begge studiene. Resultatene var de samme uavhengig om dupilumab ble gitt hver eller annenhver uke. Placebogruppene kom signifikant dårligere ut $(\mathrm{p}<0,001)$. Dupilumab-behandling var også assosiert med bedring i kløe, angst/depresjon og livskvalitet.
- Dette er to meget interessante studier, sier Marit Saunes, avdelingsoverlege ved Hudavdelingen, St. Olavs hospital, og førsteamanuensis ved Norges teknisk-naturvitenskapelige universitet.

- For pasienter med psoriasis har biologiske legemidler vært et behandlingsalternativ i flere år. Dette er første gang et humant antistoff viser effekt mot atopisk eksem, som er den andre store pasientgruppen i dermatologi. Nå gjenstår det å vurdere effekt og sikkerhet av dupilumab over lengre behandlingsperioder, sier Saunes.

\section{Kari Tveito}

Tidsskriftet

\section{Litteratur}

1. Simpson EL, Bieber E, Guttman-Yassky E et al. Two phase 3 trials of dupilumab versus placebo in atopic dermatitis. N Engl J Med 2019. E-publisert 30.9.2016.

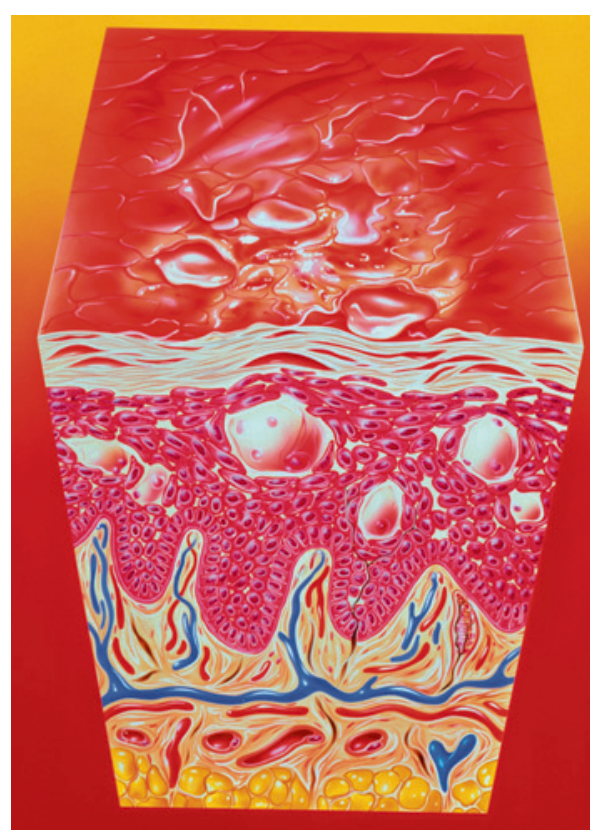

Eksem. Illustrasjon: Science Photo Library 